\title{
Evaluation of Beauty Degree of Kunming City Park Based on SBE and AHP
}

\author{
Shi Ying 1 , a \\ ${ }^{1}$ Faculty of Architecture and Urban Planning, Kunming University of Science and Technology, Oxbridge College, \\ Kunming, Yunnan, China \\ a416825883@qq.com

\begin{abstract}
The landscape resources of 10 urban parks in Kunming, such as planting water, plants, roads and articles, were investigated and evaluated by SBE and AHP. The mean value of SBE is 0.9418 , and there are 5 SBE values, and the mean value of AHP is mainly between 5 and 7. Generally speaking, the landscape of Kunming urban parks is above the average level, but there are relatively few parks with high landscape quality. The evaluation results of the two evaluation methods are analyzed, and it is concluded that the evaluators mainly pay attention to the aesthetic function of landscape; The landscape configuration forms favored by tourists are discussed.
\end{abstract}

Keywords: Landscape evaluation; SBE method; The AHP method. Kunming City Park.

\section{基于 SBE 及 AHP 法的昆明市城市公园美景度评价 石莺 ${ }^{1, a}$}

${ }^{I}$ 昆明理工大学津桥学院建筑工程学院建筑与城乡规划系 昆明, 云南, 中国 ${ }^{a} 416825883 @ q q . c o m$

\section{摘要}

全面实地调查昆明 10 个城市公园植水体、植物、道路、小品等景观资源, 运用 SBE 法和 AHP 法对 10 个公园 的典型景观样地进行调查评价。评价结果, SBE 均值最大为 0.9418 , 有 5 个 SBE 正值, AHP 均值主要在 5 7 之间, 总体来说昆明城市公园的景观处于中等偏上水平, 但景观优质的公园相对较少; 对 2 种评价方法的 评价结果进行分析, 得出评判者主要注重景观的美学功能; 探讨了游客喜爱的景观配置形式。

关键词: 景观评价; SBE 法; AHP 法; 昆明市城市公园

\section{1. 前言}

景观评价是指对景观视觉质量的评价, 是运用某 种标准, 个人或群体对景观价值作出判断, 为作出判 断所提供的证据即评价过程 ${ }^{[1]}$ 。公园景观在改善城市 生态环境、美化城市人工环境和提升城市精神文化等 方面发挥着重要作用 ${ }^{[2]}$ 。在调查基础上, 通过综合分 析全面评价、衡量景观要素 (建筑, 小品, 水景等) 和美景度之间的关系, 可以为公园景观的设计营建, 以及对现有公园绿地的改造、提高和完善等方面均起
着至关重要的作用。

\section{2. 研究区概况}

昆明市位于云贵高原中部, 属北亚热带低纬高原 山地季风气候, 为山原地貌, 三面环山, 南濒滇池, 沿湖风光绮丽, 由于地处低纬高原而形成“四季如春” 的气候, 享有 “春城” 的美誉。

对昆明市主城区范围内的公园进行实地踏查, 根 据选取的公园应遍及整个城市建成区且应选择典型 性公园的原则, 按照昆明市公园的空间分布, 选定昆 
明市主城区一环以内的翠湖公园、一二环之间的莲花 池公园、三环边的月牙塘公园、东郊的县华寺、南市 区新城世纪城片区的如意公园、西郊的郊野公园、北 郊的黑龙潭公园、北部山水新区的瀑布公园、滇池北 岸的宝丰湿地公园、滇池东岸的捞鱼河公园作为样地 采集地点, 地理位置覆盖整个主城区, 地缘上可以广 泛代表昆明市主城区的典型公园。

\section{3. 研究方法}

\section{1. 调查方法}

在勘查昆明市公园的基础上, 采用样地法调查公 园景观, 鉴于公园植被均为人工植被, 多数植物群落 面积不大, 样地面积设为 $10 \mathrm{~m} \times 10 \mathrm{~m}$; 对每个公 园景观样地多方位拍摄照片，供公园景观评分之用。

\section{2. 公园景观评价方法}

\section{2. 1. 美景度评价法（ $S B E$ 法）}

邀请 30 名城乡规划专业学生作为评判者根据景 观评价标准, 通过 PPT 照片对公园景观打分, 对数据 进行标准化处理, SBE 值为理想值, 不受评分标准和 打分制度的影响 ${ }^{[3]}$ 。SBE 值标准化处理的公式为:

$$
\begin{aligned}
& Z i j=(R i j-R j) / S j \\
& S B E i=\sum Z i j / N i
\end{aligned}
$$

式中: $Z i j$ 一一第 $\mathrm{j}$ 个观察者对第 $\mathrm{i}$ 个景观照 片的规范化美景度值

$R i j$ 一一第 $\mathrm{j}$ 个观察者对第 $\mathrm{i}$ 个景观照片的 评判值

$R j$ 一一第 $\mathrm{j}$ 个观察者对所有景观照片的评判 均值

$S j$ 一一第 $\mathrm{j}$ 个观察者对所有景观照片评判值 的标准差

$S B E i$ 一一第 $\mathrm{i}$ 个景观照片最终标准化 $\mathrm{SBE}$ 值

$N i$ 一一第 $\mathrm{i}$ 个景观照片评判的总人数

\section{2. 2. 层次分析法 (AHP 法)}

通过咨询相关专家，根据咨询结果筛选适合的指 标, 建立指标体系 ${ }^{[4]}$ 。根据专家的评分, 统计各层次 的判断矩阵, 并作一致性检验, 得到目标层和标准层 的权重值, 最后自上而下将单准则下的权重统计出总 排序权重 ${ }^{[5]}$ (表 1)。
表 1 昆明市城市公园景观评价层次总排序权重

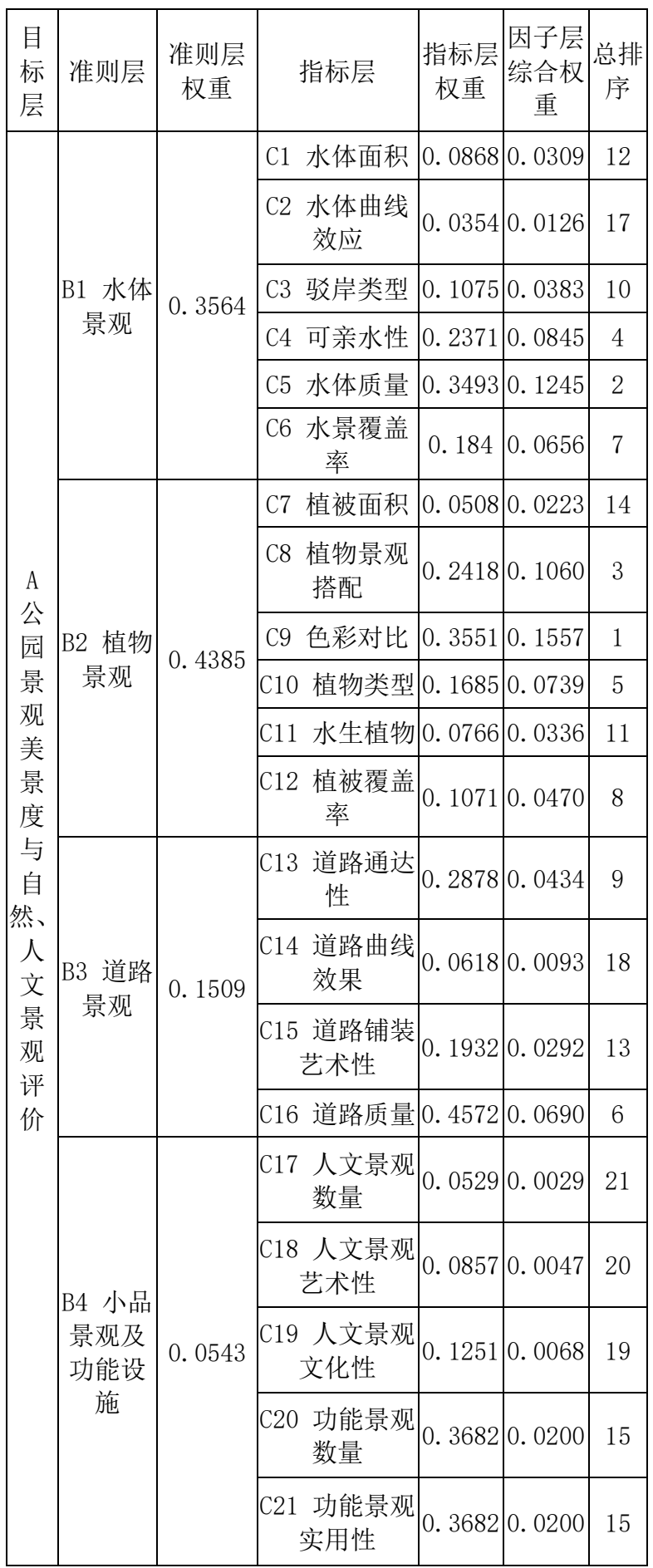

层次总排序检验满足一致性结果。

以样地调查为基础, 制定昆明市公园景观评价指 标赋分标准，并为评价因子打分，根据样地景观状态 对各评价因子打分。 


\section{4. 结果与分析}

\section{1. $S B E$ 评价结果与分析}

表 2 各公园 SBE 均值及排名

\begin{tabular}{ccc}
\hline 公园 & SBE 均值 & 排名 \\
\hline A 翠湖公园 & 0.1558 & 5 \\
B 捞鱼河公园 & 0.9107 & 2 \\
C 如意公园 & -0.9114 & 9 \\
D 郊野公园 & -1.0734 & 10 \\
E 黑龙潭公园 & -0.4784 & 8 \\
F 瀑布公园 & 0.9418 & 1 \\
G 县华寺公园 & -0.3476 & 7 \\
H 莲花池公园 & -0.1284 & 6 \\
I 宝丰湿地公园 & 0.2682 & 4 \\
J 月牙潭公园 & 0.6957 & 3 \\
\hline
\end{tabular}

由 $\mathrm{SBE}$ 评价法结果可看出公园美景度排名为: 瀑 布公园>捞鱼河公园 $>$ 月牙潭公园 >宝丰湿地公园>翠 湖公园 >莲花池公园 >是华寺公园 >黑龙潭公园 >如意 公园〉郊野公园。在 10 个公园中, 有 5 个公园 SBE 均 值为正值, 84 块样地中 46 块样地的 SBE 均值为正值, 说明昆明城市公园景观美景度质量整体一般。

\section{2. $A H P$ 法评价结果与分析}

对市民、景观设计师、管理人员等进行问卷调查、 访谈, 评分标准尽量采取量化方式, 对软性指标进行 模糊评判, 如很好、好、较好、一般、差评分采用 10 分制, 分为 10-8. 1, 8-6. 1, 6-4.1,4-2.1, 2-0 五个 等级 ${ }^{[6]}$ 。将各二级指标的记分乘以二级指标相对于评 价目标的权重, 即为该项二级指标的得分, 最后将各 二级指标得分相加换算成百分制, 即为该公园景观美 景度评价的总分。

表 3 各公园 AHP 值及排名

\begin{tabular}{ccc}
\hline 公园 & AHP 值 & 排名 \\
\hline A 翠湖公园 & 6.50 & 3 \\
B 捞鱼河公园 & 6.70 & 2 \\
C 如意公园 & 5.46 & 9 \\
D 郊野公园 & 5.96 & 6 \\
E 黑龙潭公园 & 5.37 & 10 \\
F 瀑布公园 & 5.49 & 8 \\
G 县华寺公园 & 6.02 & 5 \\
H 莲花池公园 & 6.05 & 4 \\
I 宝丰湿地公园 & 6.89 & 1 \\
J 月牙潭公园 & 5.77 & 7 \\
\hline
\end{tabular}

综合质量: 宝丰湿地公园 $>$ 捞鱼河公园 $>$ 翠湖公 园 $>$ 莲花池公园 $>$ 县华寺公园 $>$ 郊野公园 $>$ 月牙潭 公园 $>$ 瀑布公园 $>$ 如意公园 $>$ 黑龙潭公园

\section{3. $S B E$ 法与 $A H P$ 法分析比较}

表 $4 \mathrm{SBE}$ 法和 AHP 法的评价值及排名比较

\begin{tabular}{ccccc}
\hline 公园 & SBE 均值 & 排名 & AHP 值 & 排名 \\
\hline A 翠湖公园 & 0.1558 & 5 & 6.50 & 3 \\
B 捞鱼河公园 & 0.9107 & 2 & 6.70 & 2 \\
C 如意公园 & -0.9114 & 9 & 5.46 & 9 \\
D 郊野公园 & -1.0734 & 10 & 5.96 & 6 \\
E 黑龙潭公园 & -0.4784 & 8 & 5.37 & 10 \\
F 瀑布公园 & 0.9418 & 1 & 5.49 & 8 \\
G 县华寺公园 & -0.3476 & 7 & 6.02 & 5 \\
H 莲花池公园 & -0.1284 & 6 & 6.05 & 4 \\
I 宝丰湿地公园 & 0.2682 & 4 & 6.89 & 1 \\
J 月牙潭公园 & 0.6957 & 3 & 5.77 & 7 \\
\hline
\end{tabular}

将 SBE 法的评价值与 AHP 法的评价值进行比 较, 并排名（表 4）, 可知, 通过两种景观评价方法 的比较, 结果显示两种评价方法的评价结果一致性较 高, 个别样地的排序出现差异, 但总体排名趋势相似, 都反映了城市公园不同类型景观质量等级。

由表 4 可知, AHP 法与 SBE 法在景观美学评价中 的分值排序并非完全一致，存在一定的排序差异，但 总体上评价结果趋势相似。SBE 法是基于大量不同群 体的调查基础上, 以主观喜好为出发点, 是基于群体 的视觉性基础评价, 且不同群体的审美一致性较高。 AHP 法是基于定量评判的基础上，通过将评价因子定 量性描述, 并进行定性化分析, 将定量与定性相结合, 得出相对客观的景观评价结果。两种方法相结合, 评 价结果一致性较高, 说明运用 SBE 法进行景观美学 评价一定程度上可以反映景观质量等级, 也可以反映 出群体审美趋势。

水体景观中宝丰湿地公园和捞鱼河公园水体主 要来源于滇池, 公园区域属于昆明湖滨生态带的建设 区域, 是湖泊生态系统的重要组成部分, 是滇池生物 多样性最丰富的场所, 是滇池自净最有用的区域, 也 是开展湿地科普教育的基地。翠湖公园位于市中心, 有城中美玉之称, 具历史感, 湖心岛景区以清代建筑 为主。经清康熙、道光年间筑堤架桥, 堤畔遍植垂柳, 湖内种植荷花，人文、自然和美景度较高，综合排名 靠前。 


\section{5. 结论与建议}

\section{1. 结论}

通过对昆明城市公园不同类型景观实地调查的 基础上, 分别从水体景观、植物景观、道路景观、建 筑小品景观四个方面对公园美景度进行分析调研, 并 筛选 84 块景观样地, 运用 SBE 法及 AHP 法分别进 行景观美学评价, 评价不同类型景观质量效果, 并对 景观美学进行评价分析, 对城市公园的景观优化及发 展具有实践指导意义。

昆明市城市公园均为人工园林植被且群落类型 多样性丰富, 加之受时间、人力等所限, 论文研究中 选取的公园景观样地类型代表性不够强, 可能难以完 全反映公园景观质量全貌, 也未能对样地分别一年四 季景观进行多次评价; 评判者未到实地观察而仅仅是 根据样地照片打分, 难以确保准确性且表现较强的主 观性。本研究运用 SBE 法和 AHP 法相结合, 避免了使 用单一评价法造成的片面性。

通过采用 SBE 法和 AHP 法, 对公园景观的评价结 果显示其质量处中上水平, 但景观优质的植物群落较 少, 这与昆明市其他公园植物景观评价结果相似


中等水平, 有进一步改善提升的空间。对 2 种评价 方法得出的结果均值排名在前 3 名的公园景观进行 实例分析, 结果表明, 层次丰富、植物种类多样、花 多艳美或叶形、叶色独特的植物搭配和水质清澈、亲 水性驳岸、有一定水景覆盖率的水面更能吸引游客。

\section{2. 建议}

1. 色彩对比所占权重最大, 说明别致的花卉和 叶形, 叶色树种的使用, 丰富的色彩搭配, 可以增加 游客赏景中的记忆点, 获得难忘的观景体验。

2. 植物景观与水体景观在评价体系中占比较 高, 说明植物与水体的健康与否对城市公园美景有很 大的影响, 应加强后期管理与养护, 以保证景观最优。

3. 植物景观搭配所占权重比值较大, 因此乔木、 灌木、草类、藤本、花卉、竹类等相互搭配, 营造丰 富的景观层次, 可以在公园景观营造中创造丰富的视 觉效果，提升公园整体品质。

4. 鉴于人文景观文化性得分较低, 故应加强城 市文化和地方特色在城市公园的渗透, 突出公园独特 的个性。

\section{基金项目}

本文为云南省教育厅科学研究基金项目一一基 于 SBE 及 AHP 法的城市公园美景度与人文、自然景观 特征研究——以昆明市为例 (编号：2019J0363）的 成果之一。

\section{REFERENCES}

[1] Li lili, He Taiping. (2020) Plant landscape Evaluation of Nanning Flower Park based on SBE method and AHP Method. Forest Survey and Planning,3: 187-194.

[2] Lin Jun, Wei Wen. (2019) Winter landscape evaluation of Cuihu Park in Kunming based on SD method. Research of Landscape Architecture, 3:84-87.

[3] Han Li, Ma Changle. (2020)Survey and research on beauty degree of Binjiang Park based on SBE method: A case study of Binjiang Park in Kunming city. Jiangsu Agricultural Sciences, 10:137-142.

[4] Xie Shanshan.(2016) Study on plant community configuration pattern and landscape aesthetics in Zhengzhou City Park . Zhengzhou: Henan Agricultural University.

[5] Liu Ruixue, Peng Yuanyuan.(2017) Plant landscape evaluation of urban coastal green space based on AHP. Journal of northwest forestry university, $4: 288-293$.

[6] Yang Ke.(2010) Study on plant community landscape of Chengdu Comprehensive park.Ya 'an: Sichuan Agricultural University.

[7] Liu Rongfeng, Zhang Yun, Jiang Haifeng ( 2008) Plant Landscape Design of Kunming City Central Park. Journal of Southwest Forestry University, 10:57-65.

[8] Hu Tingting,Pan Qubo.(2018)Research on plant landscape configuration of Kunming Luyuhe Wetland Park . Rural Science and Technology 12: $55-56$.

[9] Gui Guohua, Yang Lei, Gui Guomin, Li Donghui, ( 2020) Landscape Evaluation of Kunming Waterfall Park. Journal of Southwest Forestry University (Social Sciences)6:92-98. 